\title{
Penerapan Metode Forward-Backward Chaining pada Sistem Pakar Pencegahan dan Pengobatan Penyakit Sapi
}

\author{
M D Irawan', A Widarma ${ }^{2}$, Y H Siregar ${ }^{3}$, Rudi $^{4}$ \\ Sistem Informasi, Fakultas Sains dan Teknologi, Universitas Islam Negeri Sumatera Utara, Indonesia ${ }^{1}$ \\ Jl. Williem Iskandar Pasar V Medan Estate 20371, Indonesia ${ }^{1}$ \\ Teknik Informatika, Fakultas Teknik, Universitas Asahan, Indonesia ${ }^{234}$ \\ Jl. Jend. Ahmad Yani, Kisaran 21219, Indonesia ${ }^{234}$ \\ muhammaddediirawan@uinsu.ac.id ${ }^{* 1}$, adiwidarma10@gmail.com², yustria.siregar@gmail.com³, \\ rudi@gmail.com ${ }^{4}$ \\ diterima: 1 Juli 2020 \\ direvisi: 19 Januari 2021 \\ dipublikasi: 1 Maret 2021
}

\begin{abstract}
Abstrak
Meningkatnya populasi ternak sapi di desa Aek Nagali khususnya di dusun V sangatlah membantu perekonomian pada masyarakat tersebut, kesehatan akan hewan ternak yang dipelihara oleh peternak menjadi hal yang penting untuk hewan itu sendiri. Sulitnya dokter hewan di daerah desa Aek Nagali sehingga kebiasaan orang di desa yang mana ketika sapi mereka sakit dan sekarat langsung di sembelih dan dagingnya diperjualbelikan. Padahal hal tersebut belum tentu sapi tersebut layak di komsumsi atau tidak karena ada penyakit sapi yang bisa menular ke manusia saat makan daging sapi tersebut. Tujuan penelitian ini membangun suatu sistem berbasis sistem pakar yang dapat memberikan gambaran umum atau keputusan. Metode yang digunakan adalah Forward Chaining dan Backward Chaining dalam mendiagnosa penyakit sapi. Pembahasan yang difokuskan dengan menerapkan aturan Forward Chaining dan Backward Chaining dan menerapkannya ke sistem. Dari hasil penelitian metode backward dan forward memberikan informasi cara pencegahan dan pengobatan pada penyakit sapi sehingga peternak bisa mengetahui langkah apa yang harus di ambil.
\end{abstract}

Kata kunci: Forward Chaining; Backward Chaining; Sistem Pakar; Penyakit Sapi

\begin{abstract}
Increasing the population of cattle in Aek Nagali village, especially in hamlet $V$, really helps the economy of the community, the health of the livestock raised by breeders is important for the animals themselves. It is difficult for veterinarians in Aek Nagali village so that it is the custom of people in the village where when their cows are sick and dying they are immediately slaughtered and the meat is traded. Even though this does not mean that the cow is suitable for consumption or not because there is a cow disease that can be transmitted to humans when eating beef. The purpose of this research is to build an expert system-based system that can provide an overview or decision. The method used is Forward Chaining and Backward Chaining in diagnosing cow disease. The discussion is focused on applying Forward Chaining and Backward Chaining rules and applying them to the system. From the results of research, the backward and forward methods provide information on how to prevent and treat cattle disease so that breeders can know what steps to take.
\end{abstract}

Keywords: Forward Chaining; Backward Chaining; Expert System; Cow Disease

\section{Pendahuluan}

Pada suatu daerah terdapat desa yaitu Desa Aek Nagali, Kecamatan Aek Kuasa, Kabupaten Asahan, Provinsi Sumatera Utara merupakan sebagian masyarakatnya adalah peternak. Salah satu ternak adalah sapi, populasi ternak sapi di desa Aek Nagali khususnya di dusun V sangatlah membantu perekonomian pada masyarakat tersebut, kesehatan akan hewan ternak yang dipelihara oleh peternak menjadi hal yang penting untuk hewan itu sendiri. Banyaknya hewan ternak di desa Aek Nagali tidak sama dengan adanya dokter hewan di daerah itu. Para perternak hanya mengetahui penyakit masuk angin atau cacingan pada hewan mereka. Untuk memanggil 
dokter hewan ke desa Aek Nagali memakan waktu yang lama karna akses jalan di desa Aek Nagali sangatlah jauh dan terjal. Jika peternak ingin memanggil dokter hewan maka peternak harus mengumpulkan beberapa peternak yang hewan mereka sakit juga.

Sulitnya dokter hewan di daerah desa Aek Nagali sehingga kebiasaan orang desa yang mana ketika sapi mereka sakit dan sekarat langsung di sembelih dan dagingnya di jual belikan. Mereka tidak mengetahui sapi tersebut layak di komsumsi atau tidak karna ada penyakit sapi yang bisa menular ke manusia saat makan daging sapi tersebut. Pada cabang ilmu kecerdasan buatan terdapat ilmu yang dapat memindahkan pengetahuan pakar ke dalam sistem. Hal tersebut dapat membantu masyarakat ketika pakar tersebut susah untuk ditemui atau tidak ada pakar pada daerah tersebut.

Dari penjelasan tersebut, ditentukanlah tujuan penelitian ini dengan mencoba mengembangkan sistem pakar agar dapat di pakai oleh para peternak dan masyarakat umum juga mengetahui dan mengenali gejala-gejala penyakit pada ternak sapi menggunakan metode forward chaining dan backward chaining, adapun beberapa peneliti yang sudah membahas tentang sistem pakar dan penyakit sapi dengan metode certainty factor dengan data penyakit Brucellosis, Infection Bovine Rinotracheitis, Johnes's Disease, Antraks, Sapi Gila, Bovine Viral Diarrhea [1]. Terdapat juga pada penelitian lain dengan metode yang sama namun data penyakit sedikit berbeda yaitu, Antraks, Kudis (Scabies), Sapi Ingusan, Sapi Ngorok, Sapi Demam, Sapi Surra, dan Foot Rot [2]. Pada penelitian lain dengan metode yang berbeda menggunakan metode forward chaining untuk mengidentifikasi penyakit dan pengobatan serta mengembangkan sistem pakar menggunakan metode RAD (Rapid Application Development) [3]. Penelitian lain dengan metode yang sama yaitu forward chaining membahas tentang penyakit Tuberkolosis, Antraks, Radang paha, Brucellosis,Leptosirosis, Vibriosis, Endometritis, Mastitis, Penyakit jamur, Pneumonia, PMK(Penyakit mulut dan kuku), IBR, BVD , Ngorok [4]. Dari penelitian yang telah dijelaskan pada diagnosa penyakit sapi terdapat beberapa metode yang digunakan seperti centainty factor dan forward chaining. Pada penelitian ini menggabungkan metode forward chaing dan backward chaining.

Kombinasi metode forward chining dan backward chaining pernah dilakukan dalam mendiagnosa penyakit ayam [5], serta analisa efectivitas metode tersebut yang menghasilkan klasifikasi dari metode forward dan backward [6]. Selain kombinasi terdapat juga penelitian tentang perbandingan strategi penalaran foward chaining dan backward chaining [7].

Hal tersebut jadikan perbedaan mendasar dari penelitian sebelumnya. Penggabungan metode ini tidak menggabungkan metodenya namun membedakan penggunaan metodenya. Metode Forward Chaining digunakan dalam diagnosa penyakit sapi. Sedangkan Metode Backward Chaining digunakan dalam diagnosa penyakit sapi pencegahan penyakit sapi.

\section{Kajian Pustaka}

Kajian pustaka merupakan teori-teori tentang sistem pakar, forward chaining dan backward chaining serta UML dalam tools analisa dan desain sistem.

\subsection{Sistem Pakar}

Secara umum, sistem pakar merupakan alat bantu pangganti pakar dalam hal diagnosa masalah-masalah tertentu. Pengganti yang dimaksud bukan mengganti pakar menjadi sistem, namun memasukkan keahlian pakar kedalam sistem. Sehingga sistem tersebut dapat menjawab masalah-masalah yang sesuai dengan kepakaran sistemnya. Terdapat penelitian tentang sistem pakar dalam diagnosa pada penyakit manusia, sistem tersebut menggantikan pakar penyakit tersebut kepada sistem [8], [9], [10], [11], [12]. Selain pada manusia sistem pakar juga dilakukan untuk menggantikan pakar tanaman [13], [14]. Begitu juga banyak terdapat 
penelitian tentang diagnosa tentang penyakit hewan seperti sumber penelitian pada pendahuluan.

\subsection{Forward Chaining dan Backward Chaining}

Forward Chaining adalah proses penelusuran yang dimulai dengan menampilkan kumpulan data atau fakta yang meyakinkan menuju kesimpulan akhir[15]. Sedangkan Backward Chaining adalah proses berpikir ke belakang dimulai dengan tujuan dan kemudian melacak jalan yang akan mengarah ke tujuan itu, mencari bukti bahwa kondisi terpenuhi. Mencocokkan fakta atau pernyataan dimulai dari sisi kanan (lalu pertama)[16].

\subsection{Penyakit Sapi}

Data penyakit sapi didapat dengan melakukan wawancara dengan salah satu mantri hewan yang ada di Asahan. Data yang di ambil adalah gejala gejala penyakit, jenis penyakit, khususnya penyakit Anthrax, Pink Eyes, Mastitis, Cacingan, Bloat atau Tympani.

\subsection{Analisa dan Desain Menggunakan UML}

Tahapan analisa dan desain merupakan tahapan dalam pengembangan sistem. Dalam hal ini digunakan UML seperti usecase, activity diagram, sequensial diagram dan class diagram[17].

\section{Metode Penelitian}

Di dalam melakukan pelitian perlu membuat kerangka kerja, supaya penelitian yang di lakukan bisa berjalan dengan sistematis. Dengan ini kerangka kerja penelitian, peneliti dapat mengambil keputusan dan sikap yang tepat untuk mengatasi masalah saat penelitian.

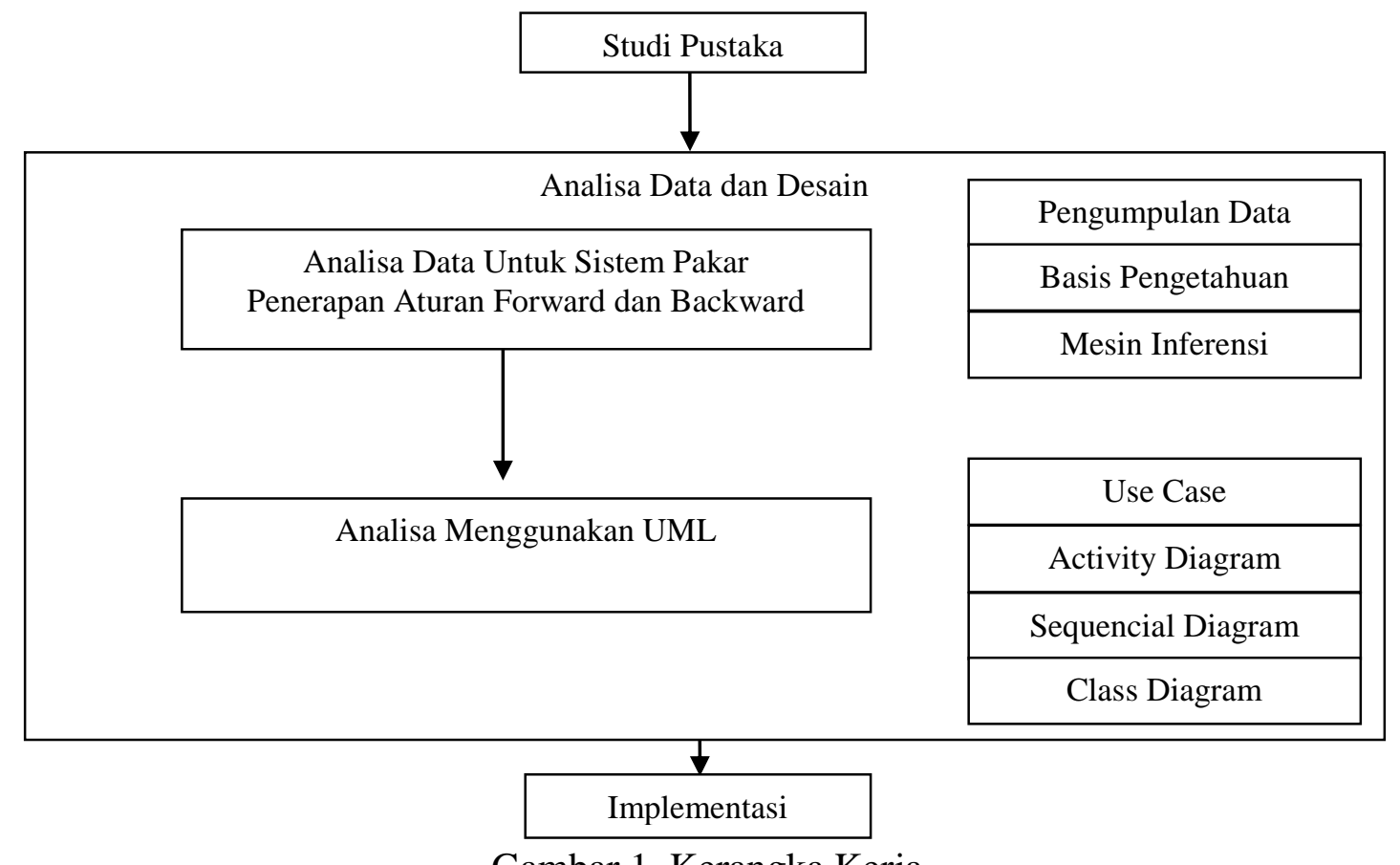

Gambar 1. Kerangka Kerja

\subsection{Studi Pustaka}

Studi pustaka terdiri dari di kutip dari jurnal yang akan di implementasikan. Studi pustaka merupakan bagian dari kegiatan studi literatur.

\subsection{Analisa dan Desain}


Dalam hal ini analisa adalah yang harus dilakukan dalam fase pengembangan untuk membacakan suatu masalah sudah ada dan mengidentifikasi kelemahan, kekuatan dan perbaikan sistem yang sudah ada dan mengidentifikasi penyebab, penentuan solusi, dan kebutuhan yang di perlukan informasi sistem. Ada beberapa yang di butuhkan untuk analisa antara lain

1. Analisa data untuk sistem pakar yang terdiri dari data setiap penyakit pada sapi dan memiliki kriteria gejala masing-masing.

2. Analisa data menggunakan UML (Unified Modeling Language), Use Case Diagram, Activity Diagram dan Sequence Diagram.

Desain merupakan bentuk yang mampu menjelaskan berbagai bagian-bagian tampilan dan terkaitan antar bagian dalam keseluruhannya. Desain dapat juga menguraikan kemampuan memecahkan suatu informasi atau materi menjadi komponen-komponen yang leih kecil hingga di pahami.

\subsection{Implementasi}

Implementasi merupakan tahapan yang dilaksanakan dalam meletakkan sistem supaya siap dioperasikan. Adapun komponen dibutuhkan dalam implementasi sistem yaitu perangkat keras (Hardware), perangkat lunak (Software).

\section{Hasil dan Pembahasan}

Berikut hasil dan pembahasan dijelaskan sesuai tahapan metode penelitian yang telah di paparkan pada gambar kerangka kerja.

\subsection{Analisa Data}

Data yang di gunakan penelitian ini ialah di ambil dari hasil wawancara sesuai kajian pustaka 2.3 penyakit sapi.

\section{Pengumpulan Data}

Data-data yang di peroleh selama proses pengumpulan data terdiri dari data gejala, data penyakit.

a. Data Gejala

Adapun gejala yang terdapat di aplikasi diagnosa pencegahan dan pengobatan pada sapi ini ada dua puluh gejala. Gejala gejala tersebut seperti yang di lihat dalam tabel 1 berikut.

Tabel 1. Data Gejala

\begin{tabular}{|l|l|}
\hline Kode & \multicolumn{1}{|c|}{ Jenis Gejala } \\
\hline JG01 & Deman tinggi \\
\hline JG02 & Sulit bernafas \\
\hline JG03 & Kehilangan nafsu makan \\
\hline JG04 & Keluar darah dari salah satu lubang tubuh \\
\hline JG05 & Pembengkaan di bawa leher, dada, perut dan tulang rusuk \\
\hline JG06 & Air susu bercampur nana dan darah \\
\hline JG07 & Kelenjar pada saluran air susu \\
\hline JG08 & Air susu keluar tidak normal \\
\hline JG09 & Bulu kusam dan kusam \\
\hline JG10 & Perut buncit \\
\hline JG11 & Lemah \\
\hline JG12 & Pucat pada selaput lendir mata \\
\hline JG13 & Mencret \\
\hline
\end{tabular}




\begin{tabular}{|c|l|}
\hline Kode & \multicolumn{1}{|c|}{ Jenis Gejala } \\
\hline JG14 & Perut kiri membesar \\
\hline JG15 & Pinggang membungkuk \\
\hline JG16 & Nafas cepat dan pendek \\
\hline JG17 & Selaput lendir dan katup bengkak \\
\hline JG18 & Tahi mata menjadi lendir bernana \\
\hline JG19 & Terus menerus keluar air mata \\
\hline JG20 & Memakan Tanah \\
\hline
\end{tabular}

b. Data Penyakit

Adapun jumlah penyakit yang diolah dalam aplikasi diagnosa pencegahan dan pengobatan pada sapi ini ada lima penyakit. Penyakit tersebut seperti yang di lihat dalam tabel 2 berikut.

Tabel 2. Data Penyakit

\begin{tabular}{|c|c|}
\hline Kode Penyakit & Nama Penyakit \\
\hline KP1 & Anhtrax \\
\hline KP2 & Pink eyes \\
\hline KP3 & Mastitis \\
\hline KP4 & Cacingan \\
\hline KP5 & Bloat atau tympani \\
\hline
\end{tabular}

c. Data Pencegahan penyakit

Adapun jumlah pencegahan yang diolah dalam aplikasi diagnosa pencegahan dan pengobatan pada sapi ini ada lima pencegahan. Pencegahan tersebut seperti yang di lihat dalam tabel 3 berikut.

Tabel 3 Data Pencegahan

\begin{tabular}{|c|c|}
\hline Kode Pencegahan & Nama Pencegahan \\
\hline KC1 & Pemberian Obat Cacing \\
\hline KC2 & Pemerasan Rutin \\
\hline KC3 & Teteskan Obat Mata \\
\hline KC4 & Makanan Di jaga \\
\hline KC5 & Di Kubur \\
\hline
\end{tabular}

Dari pengetahuan berupa gejala dan penyakit pada sapi, maka dapat di buat basis pengetahuan berupa hubungan atau terkaitan yang ada antara gejala dan penyakit pada sapi.

2. Basis Pengetahuan

Dari pengetahuan berupa gejala dan penyakit pada sapi, maka dapat di buat basis pengetahuan berupa hubungan atau terkaitan yang ada antara gejala dan penyakit pada sapi. Basis pengetahuan tersebut dapat di lihat pada tabel 4 :

Tabel 4 Basis Pengetahuan

\begin{tabular}{|c|c|c|c|c|c|}
\hline \multirow{2}{*}{$\begin{array}{c}\text { Kode } \\
\text { Gejala }\end{array}$} & \multicolumn{5}{|c|}{ Kode Penyakit } \\
\cline { 2 - 6 } & KP1 & KP2 & KP3 & KP4 & KP5 \\
\hline JG01 & $*$ & & & & \\
\hline JG02 & $*$ & & & & \\
\hline JG03 & $*$ & & $*$ & $*$ & \\
\hline
\end{tabular}




\begin{tabular}{|c|c|c|c|c|c|}
\hline \multirow{2}{*}{$\begin{array}{c}\text { Kode } \\
\text { Gejala }\end{array}$} & \multicolumn{5}{|c|}{ Kode Penyakit } \\
\hline & KP1 & KP2 & KP3 & KP4 & KP5 \\
\hline JG04 & $*$ & & & & \\
\hline JG05 & $*$ & & & & \\
\hline JG06 & & & $*$ & & \\
\hline JG07 & & & $*$ & & \\
\hline JG08 & & & $*$ & & \\
\hline JG09 & & & $*$ & & \\
\hline JG10 & & & & $*$ & \\
\hline JG11 & & & & $*$ & \\
\hline JG12 & & & & $*$ & \\
\hline JG13 & & & & $*$ & \\
\hline JG14 & & & & & $*$ \\
\hline JG15 & & & & & $*$ \\
\hline JG16 & & & & & $*$ \\
\hline JG17 & & $*$ & & & \\
\hline JG18 & & $*$ & & & \\
\hline JG19 & & $*$ & & & \\
\hline JG20 & & & & $*$ & \\
\hline
\end{tabular}

3. Mesin Inferensi

Mesin inferensi digambarkan dalam bentuk pohon keputusan yang digunakan untuk mengetahui fakta dan kesimpulan.

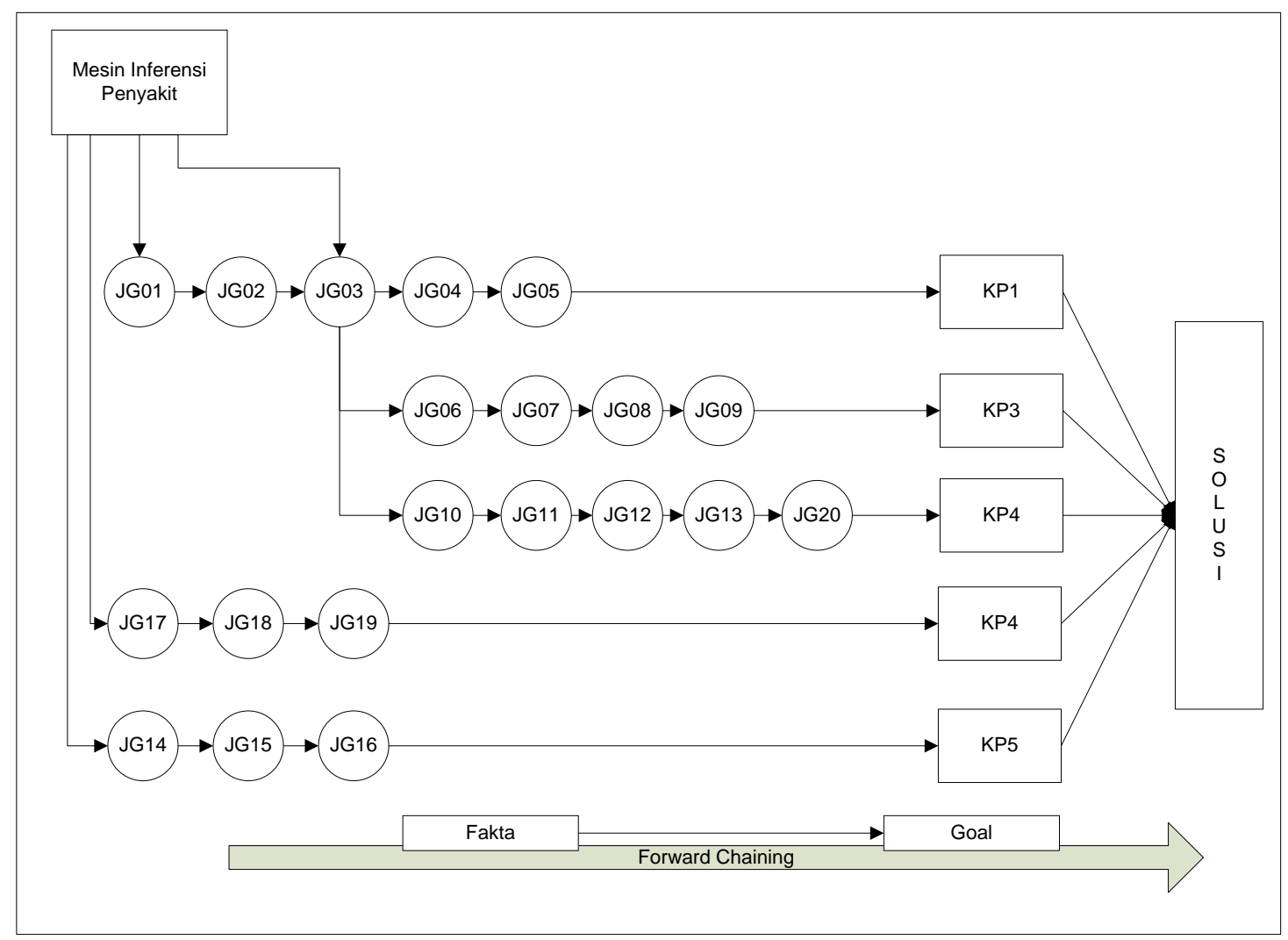

Gambar 2. Mesin Inferensi Forward Chaining Penyakit Sapi 
Mesin inferensi menggunakan forward chaining dalam mendiagnosa penyakit sapi. Dimulai dari fakta-fakta gejala sampai ke goal. Dari gambar 2 merupakan mesin pencarian solusi dari penyakit penyakit sapi dengan gejala-gejala penyakit sapi tersebut. Setelah mesin inferensi terbentuk aturan produksi sebagai berikut.

Tabel 5. Aturan Produksi

\begin{tabular}{|c|l|c|}
\hline No & \multicolumn{1}{|c|}{ Aturan Produksi } & \multicolumn{1}{|c|}{ Goal } \\
\hline 1 & IF JG01 AND JG02 AND JG03 AND JG04 THEN JG05 & KP1 \\
\hline 2 & IF JG03 AND JG06 AND JG07 AND JG08 THEN JG09 & KP2 \\
\hline 3 & $\begin{array}{l}\text { IF JG03 AND JG10 AND JG11 AND JG12 AND JG13 THEN } \\
\text { JG20 }\end{array}$ & KP3 \\
\hline 4 & IF JG17 AND JG18 THEN JG19 & KP4 \\
\hline 5 & IF JG14 AND JG15 THEN JG16 & KP5 \\
\hline
\end{tabular}

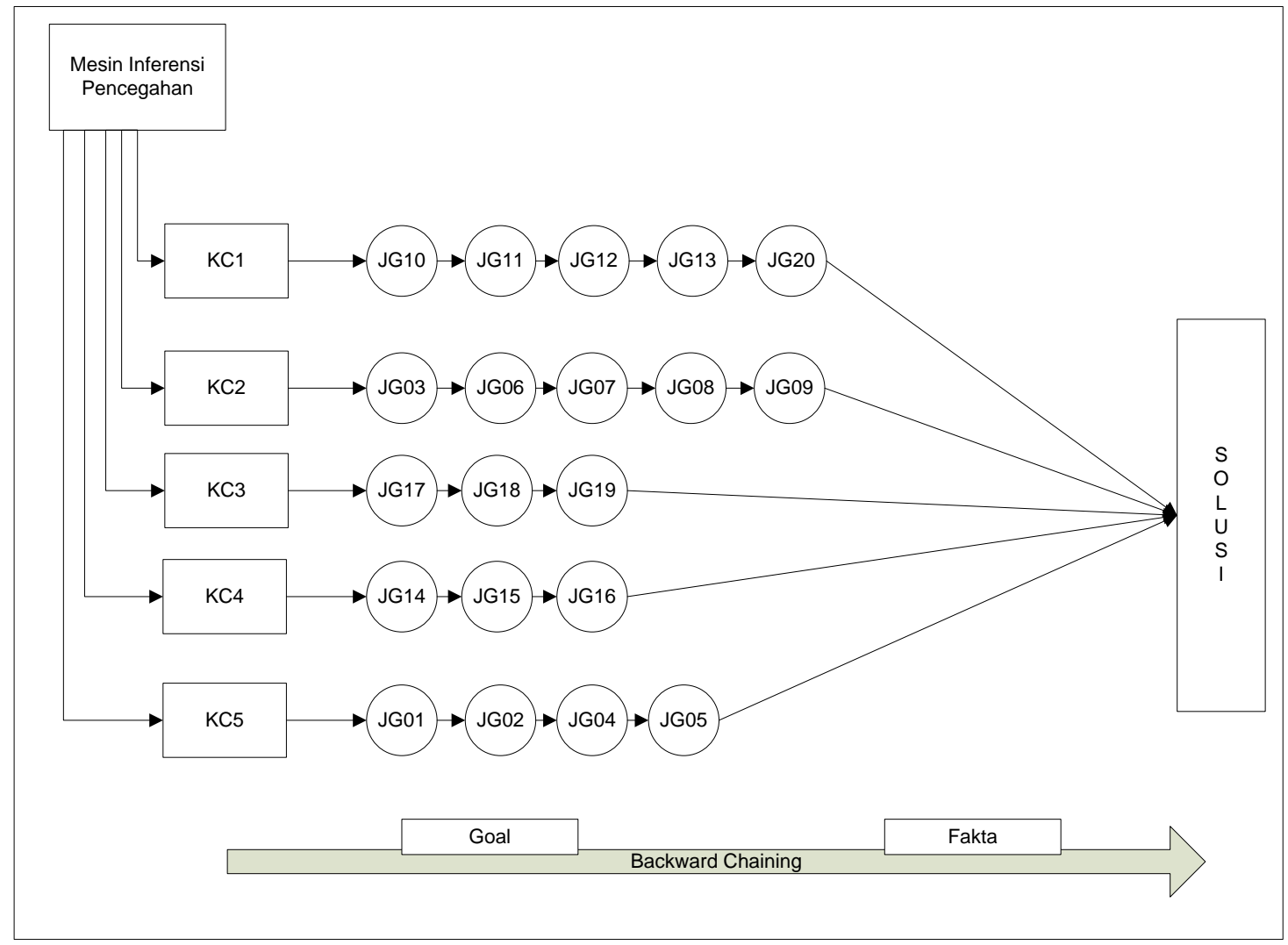

Gambar 3. Mesin Inferensi Backward Chaining Pencegahan

Mesin inferensi backward chaining digunakan dalam proses pencegahan penyakit. Dimulai dari goal hingga ke fakta-fakta yang diperoleh. Dari gambar 3 merupakan mesin pencarian solusi dari pencegahan penyakit sapi dengan fakta- fakta gejala tersebut. Setelah mesin inferensi terbentuk aturan produksi sebagai berikut.

Tabel 6. Aturan Produksi

\begin{tabular}{|c|c|l|}
\hline No & Goal & \multicolumn{1}{c|}{ Aturan Produksi } \\
\hline 1 & KC1 & IF JG10 AND JG11 AND JG12 AND JG13 THEN JG20 \\
\hline 2 & KC2 & IF JG03 AND JG06 AND JG07 AND JG08 THEN JG09 \\
\hline 3 & KC3 & IF JG17 AND JG18 THEN JG19 \\
\hline
\end{tabular}




\begin{tabular}{|c|c|l|}
\hline No & Goal & \multicolumn{1}{c|}{ Aturan Produksi } \\
\hline 4 & KC4 & IF JG14 AND JG15 THEN JG16 \\
\hline 5 & KC5 & IF JG01 AND JG02 AND JG04 THEN JG05 \\
\hline
\end{tabular}

\subsection{Analisa dan Desain Menggunakan UML}

1. Use Case Diagram

Use Case Diagram menjelaskan apa yang dilakukan oleh aktor terhadap sistem.

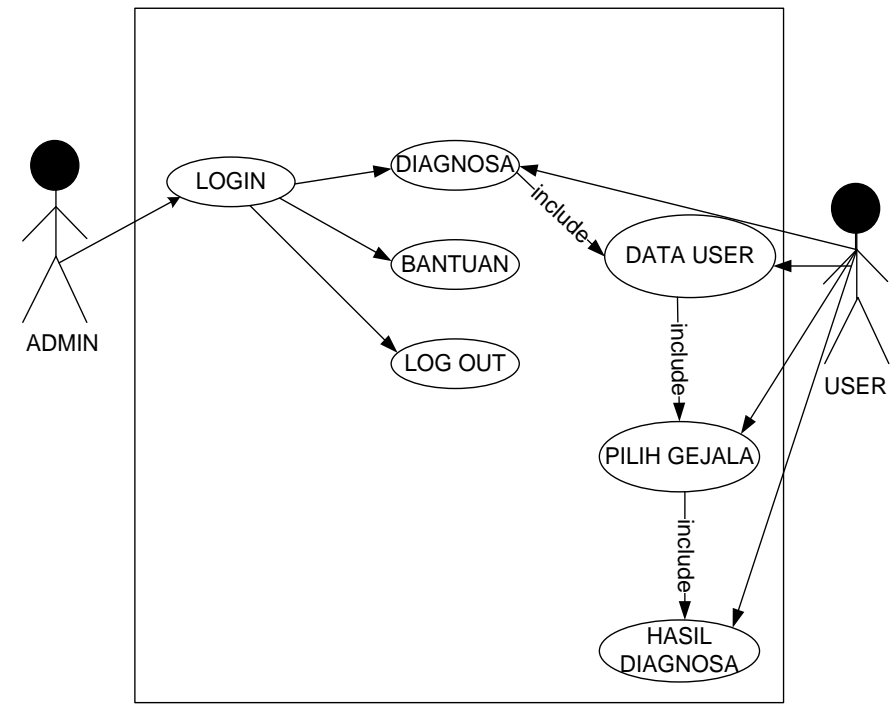

Gambar 4. Use Case Diagram

Aktor admin dalam mengakses sistem dapat dilihat dari case gambar 4. Dimulai dari login, setelah itu dapat mengakses menu diagnosa, menu bantuan dan logout. Aktor user dala mengakses sistem tidak perlu melakukan proses login. Menu yang diakses oleh aktor user adalah data user, pilih gejala dan hasil diagnosa.

2. Activity Diagram

Berikut gambar activity diagram admin dalam proses pengaksesan sistem.

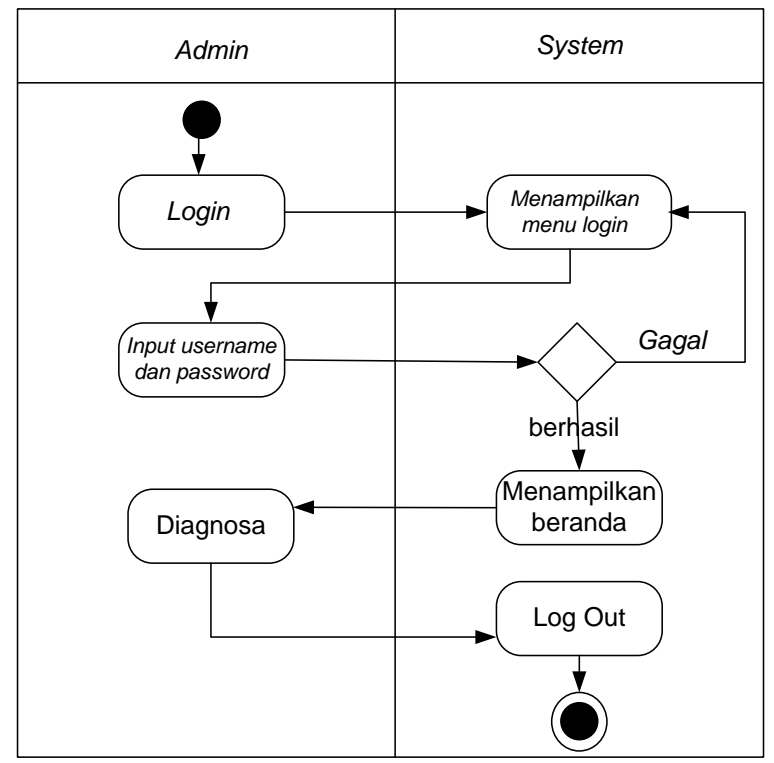

Gambar 5. Activity Diagram 
Admin membuka sistem, kemudian sistem akan menampilkan halaman menu Login dan saat berhasil Login maka akan muncul menu utama, di dalam menu tersebut akan memilih sub menu yang ada dalam menu utama. Bagi user tidak perlu login, user dapat langsung melakukan diagnosa penyakit.

\section{Sequence Diagram menu Diagnosa}

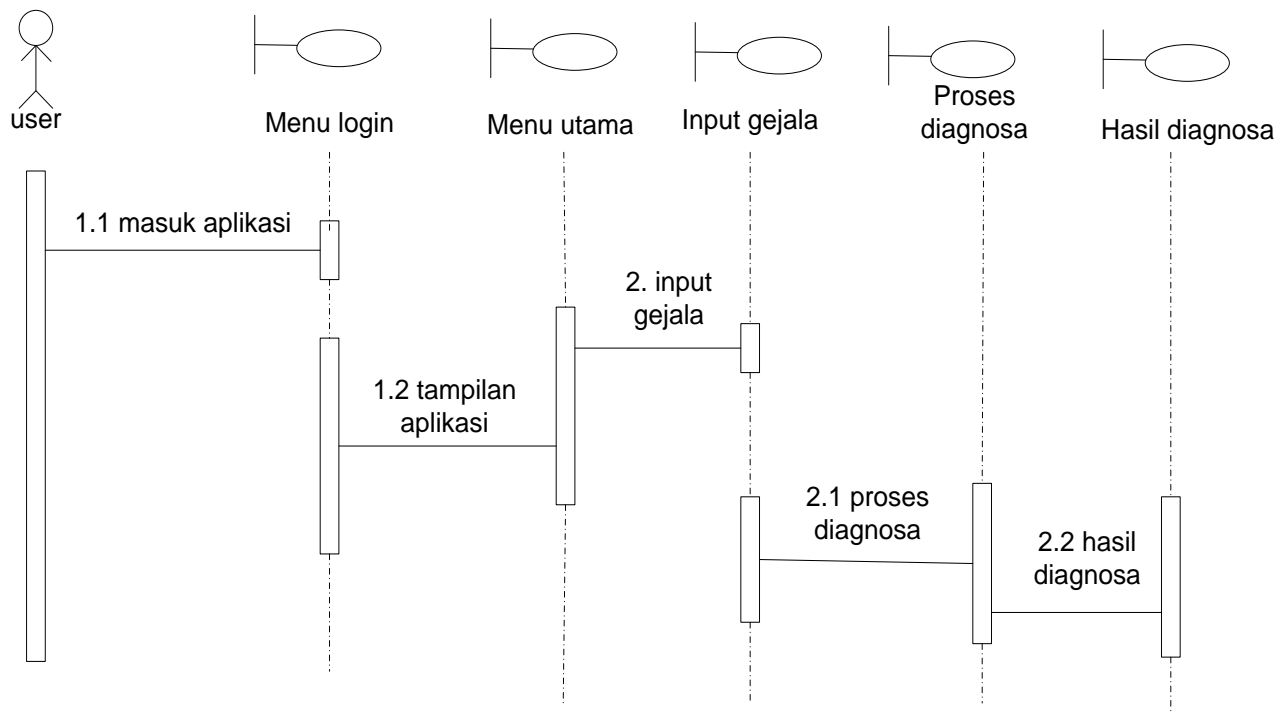

Gambar 6. Sequence Diagram menu Diagnosa

Pada gambar alur Sequence Diagram gambar 6 menunjukan sistem alur dari user melakukan proses diagnosa penyakit sapi, langkah pertama sesuai dengan alur gambar 6 bahwasanya jika user menginput data terlebih dahulu. Kemudian data yang telah dimasukan akan diproses terlebih dahulu lalu prosesnya akan mengeluarkan hasil diagnosa.

\section{Class Diagram}

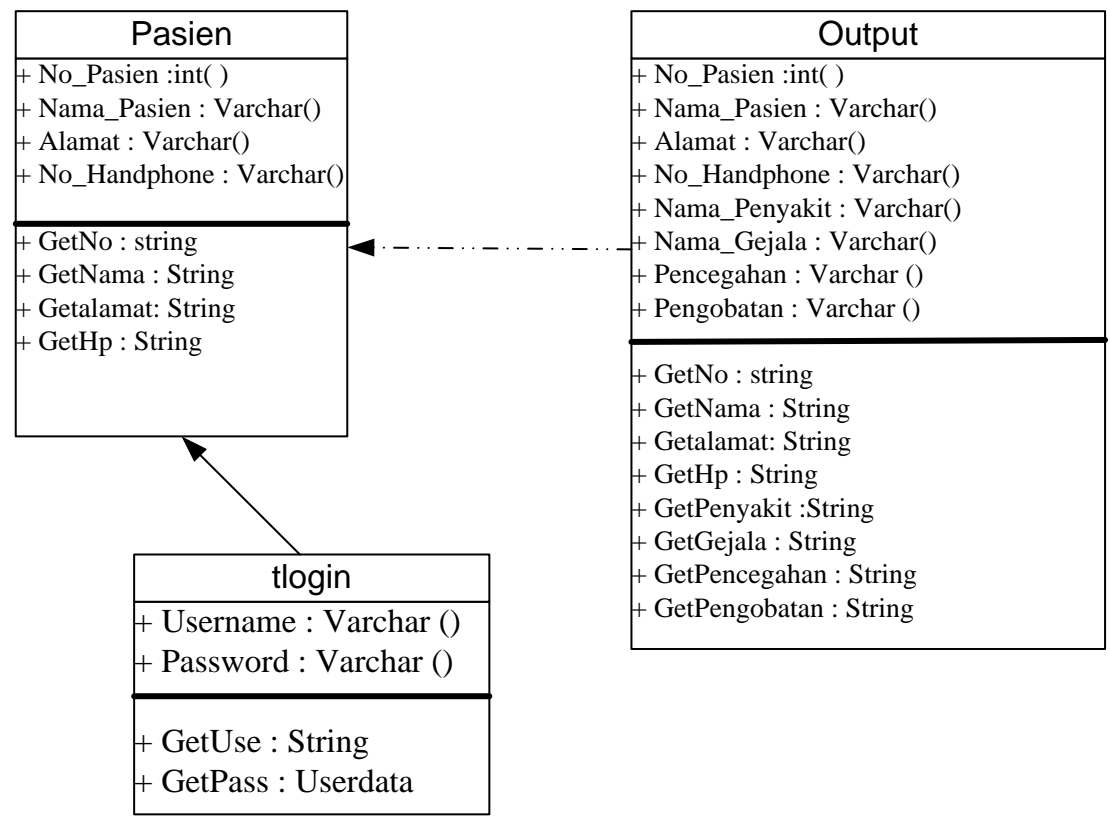

Gambar 7. Class Diagram 
Gambar 7 menggambarkan hubungan dari masing-masing kelas yang terdiri dari kelas pasien, kelas output dan kelas tlogin.

\subsection{Implementasi}

Implementasi tahap pengkodean terhadap bahasa pemrograman yang digunakan.

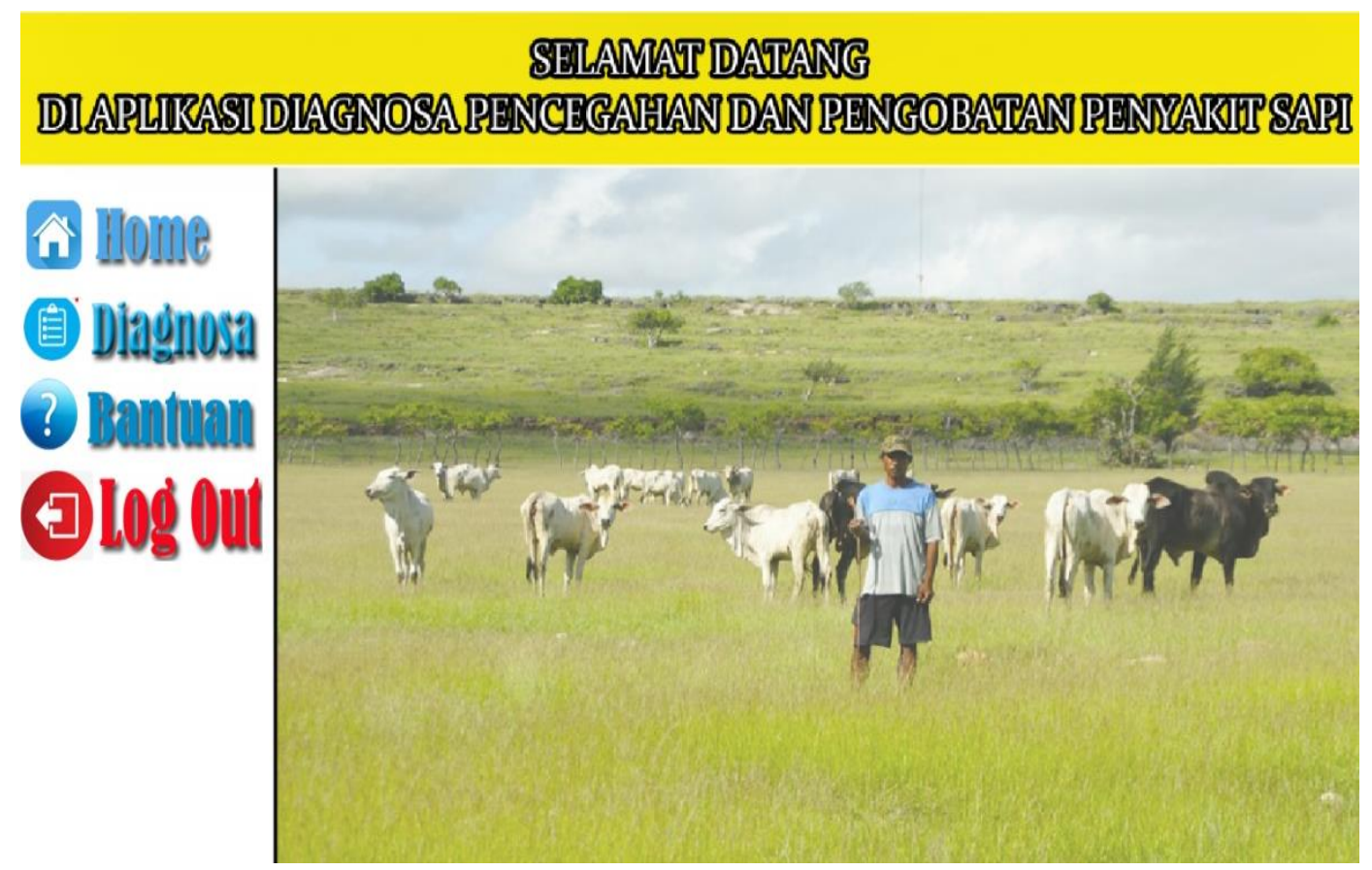

Gambar 8. Menu Utama

Dari gambar menu utama gambar 8 terdapat menu-menu yang dapat diakses seperti menu diagnosa, menu bantuan dan logout.

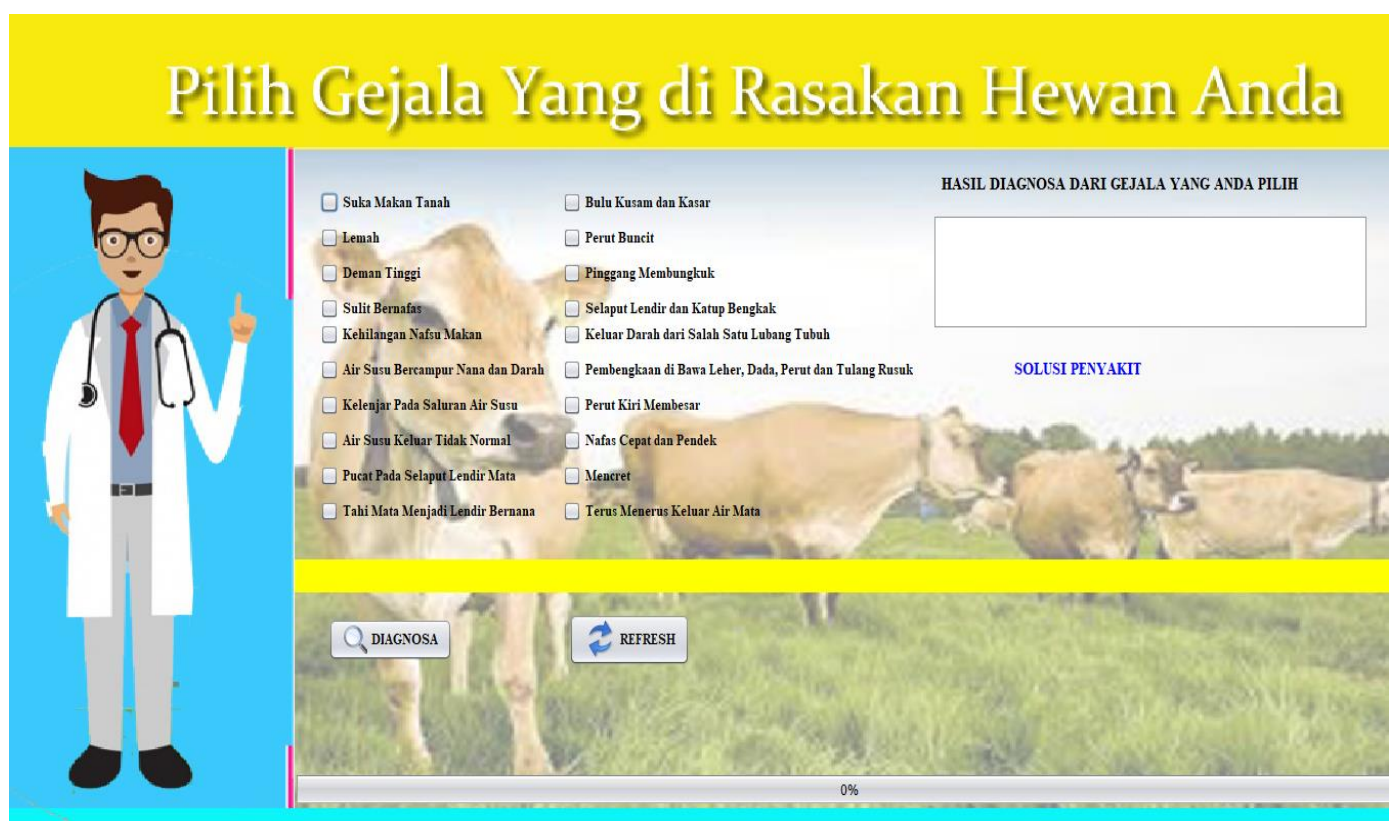

Gambar 9. Menu Diagnosa Penyakit (Forward Chaining) 
Dari gambar 9 menu diagnosa penyakit adalah tempat mendiagnosa dengan memilih faktafakta yang terjadi sehingga hasil diagnosa di simpulkan.

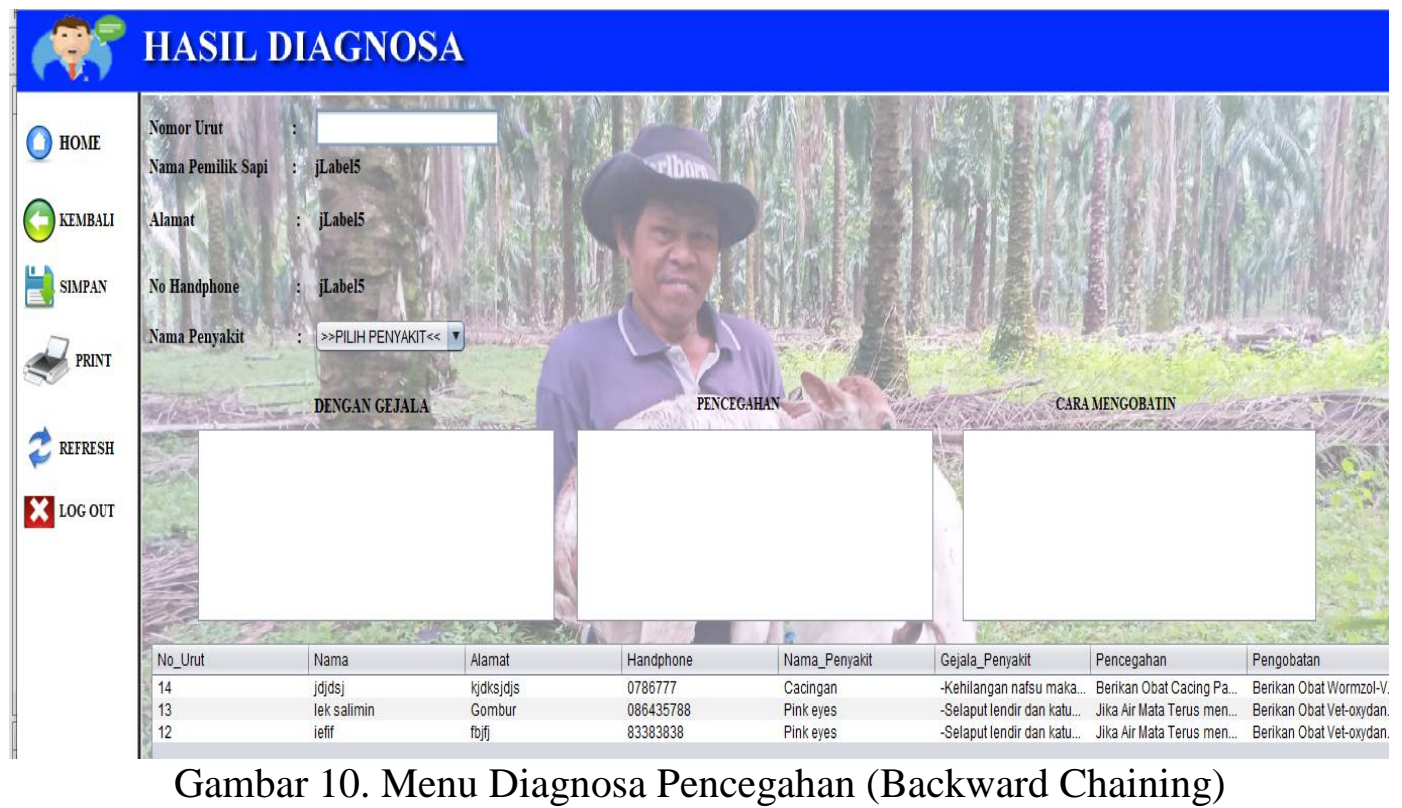

Dari gambar 10 menu diagnosa pencegahan penyakit adalah tempat mendiagnosa dengan memilih penyakit kemudian memberikan informasi sesuai fakta-fakta yang terjadi. Setelah itu dapat disimpulkan cara pengobatan dan pencegahannya.

\section{Kesimpulan}

Dari hasil penelitian yang telah dilakukan, maka dapat diambil beberapa kesimpulan. Sistem aplikasi yang dibuat dengan metode forward chaining dan backward chaining dapat melakukan diagnosa penyakit maupun cara pencegahan dan pengobatannya. Tidak semua penyakit mempunyai gejala yang sama, contoh ternak sapi kandang dengan ternak sapi yang di liarkan gejala penyakit ya hampir berbeda walau penyakit yang sama.

\section{Daftar Pustaka}

[1] S. Sibagariang, "Sistem Pakar Diagnosa Penyakit Sapi Dengan Metode Certainty Factor Berbasis Android," J. TIMES, vol. 3, no. 2, pp. 35-39, 2008.

[2] R. Handika and D. A. Jakaria, "Sistem pakar diagnosa penyakit sapi dengan metode certainty factor," Jumantaka, vol. 1, no. 1, p. 103, 2018.

[3] W. D. Prasetyo and R. Wahydi, "SISTEM PAKAR DIAGNOSIS PENYAKIT TERNAK SAPI MENGGUNAKAN METODE FORWARD CHAINING BERBASIS WEBSITE RESPONSIF EXPERT SYSTEM FOR DIAGNOSING CATTLE DISEASES USING FORWARD Wisnu Dwi Prasetyo , Rizki Wahyudi," vol. 2, no. 1, pp. 13-21, 2019.

[4] M. M. Jannan and H. Supriyono, "Sistem Pendukung Keputusan Untuk Penyakit Sapi Berbasis Android," Emit. J. Tek. Elektro, vol. 18, no. 2, pp. 8-13, 2018.

[5] R. I. Samsudin, "Penerapan Sistem Pakar Diagnosa Dini Penyakit Lambung Menggunakan Metode Forward Chaining," Sistemasi, vol. 7, no. 1, pp. 30-37, 2018.

[6] I. Akil, "ANALISA EFEKTIFITAS METODE FORWARD CHAINING DAN BACKWARD CHAINING PADA SISTEM PAKAR,” J. Pilar Nusa Mandiri, vol. 13, no. 1, pp. 35-42, 2017.

[7] A. Al-Ajlan, "The Comparison between Forward and Backward Chaining," Int. J. Mach. Learn. Comput., vol. 5, no. 2, pp. 106-113, 2015. 
[8] E. R. Ritonga and M. D. Irawan, "SISTEM PAKAR DIAGNOSA PENYAKIT PARUPARU," J. Comput. Eng. Syst. Sci., vol. 2, no. 1, pp. 39-47, 2017.

[9] P. Ananta Dama Putra, I. K. Adi Purnawan, and D. Purnami Singgih Putri, "Sistem Pakar Diagnosa Penyakit Mata dengan Fuzzy Logic dan Naïve Bayes," J. Ilm. Merpati (Menara Penelit. Akad. Teknol. Informasi), vol. 6, no. 1, p. 35, 2018.

[10] I. P. B. Krisnawan, I. K. Gede, D. Putra, and I. P. A. Bayupati, "Sistem Pakar Diagnosa Penyakit Kulit dan Kelamin Dengan Metode Certainty Factor dan Fuzzy Logic," vol. 2, no. 3, pp. 351-360, 2014.

[11] A. O. J and J. I. A, "Expert System for Diagnosis Neurodegenerative Diseases," Int. J. Comput. Inf. Tecknology, vol. 04, no. July 2015, pp. 2-7, 2018.

[12] C. P. C. Munaiseche, D. R. Kaparang, and P. T. D. Rompas, "An Expert System for Diagnosing Eye Diseases using Forward Chaining Method," IOP Conf. Ser. Mater. Sci. Eng., vol. 306, no. 1, 2018.

[13] M. D. Irawan and M. K. I. Nasution, "Rancang Bangun Sistem Pakar Mendiagnosa Penyakit Tanaman Kelapa Sawit Menggunakan Metode Bayes Berbasis Android (Studi Kasus : Perkebunan PTPN 4 Air Batu)," JurTI (Jurnal Teknol. Informasi), vol. 2, no. 1, pp. 15-23, 2018.

[14] S. Hawa, Abdullah, and Usman, "Sistem Pakar Diagnosa Penyakit Pada Tanaman Kakao Menggunakan Metode Forward Chaining (Studi Kasus Dinas Perkebunan Indragiri Hilir)," Sistemasi, vol. 4, no. 2, pp. 1-8, 2015.

[15] K. Rukun, B. H. Hayadi, I. Mouludi, A. Lubis, Safril, and Jufri, "Diagnosis of toddler digestion disorder using forward chaining method," 2017 th Int. Conf. Cyber IT Serv. Manag. CITSM 2017, 2017.

[16] A. M. Tambunan, S. R. Siringoringo, R. Aruan, P. I. Aisyah, and D. Sitanggang, “An expert system for diagnosing plant diseases using certainty factor and backward chaining based on android," J. Phys. Conf. Ser., vol. 1230, no. 1, pp. 1-7, 2019.

[17] M. D. Irawan and S. A. Simargolang, "Implementasi E-Arsip Pada Program Studi Teknik Informatika," JurTI (Jurnal Teknol. Informasi), vol. 2, no. 1, pp. 67-84, 2018. 